\title{
University codes of ethics: Legal nature and regulatory effect
}

\author{
Maria M. Panarina*, Olga V. Fonotova \\ National Research University Higher School of Economics (NRU HSE), \\ Moscow, Russian Federation, \\ *mmpanarina@hse.ru
}

\begin{abstract}
The issues of determining the subject of the code of ethics of a higher educational institution, identifying its legal characteristics, as well as the particularities of applying this regulator of relations are yet to be studied in Russia. In order to fill the gap in legal knowledge, we have made an attempt, starting with the analysis of the ethics of education in the broad sense, to generalize the Russian and foreign experience in adopting and applying codes of ethics and offer a modern vision of the essence and regulatory function of ethical codes in the practice of educational institutions. The study was conducted using general scientific and special methods of cognition: logical, functional, systemicstructural, methods of generalization, synthesis, induction, and deduction. Certain material conclusions are made based on the sociological research method. The code of ethics of a higher educational institution is a code of conduct for a good faith participant in the educational process. The code is a compromise between different types of ethics: that of a teacher and a student, of a student and an administrative employee. In this regard, the process of discussing specific practical cases and reflection in the code of effective scenarios of interaction between the parties in critical situations are of particular value. In their legal essence, codes of ethics are normative acts, but traditionally they are not regarded as legal acts, as they are adopted by bodies of professional communities and are not often supported by the power of state coercion.
\end{abstract}

Key words: higher education, ethics of science, ethics of education, code of ethics, University code of ethics

Conflicts of interest. The authors declared no conflicts of interest.

The participation of the authors: Panarina M.M. - introduction, search, analysis and scientific elaboration of the materials, general overview, conclusion; Fonotova O.V. - search for materials, legal analysis, conclusions, structure and editing, translation of the article into English.

Article received 2 nd November 2020

Article accepted 15th April 2021

\section{For citation:}

Panarina, M.M., Fonotova, O.V. (2021) University codes of ethics: Legal nature and regulatory effect. RUDN Journal of Law. 25 (2), 414 - 433. DOI: 10.22363/2313-2337-2021-25-2414-433

(C) Panarina M.M., Fonotova O.V., 2021

This work is licensed under a Creative Commons Attribution 4.0 International License https://creativecommons.org/licenses/by/4.0 


\title{
Университетские кодексы этики: правовая сущность и регулирующее воздействие
}

\author{
М.М. Панарина*, О.В. Фонотова \\ Национальный исследовательский университет «Высшая школа экономики», \\ 2. Москва, Российская Федерачия, \\ mmpanarina@hse.ru
}

\begin{abstract}
Аннотация. Вопросы определения предмета этического кодекса высшего учебного заведения, выявления его правовых характеристик, а также особенности применения на практике являются малоизученными в России. С целью восполнить отмеченный пробел в правовом знании мы предприняли попытку, начав с анализа этики образования в широком смысле, обобщить российский и зарубежный опыт внедрения кодексов этики и предложить современное видение сущности и регулятивной функции этических сводов. Исследование проведено с использованием общенаучных и специальных методов познания: логического, функционального, системно-структурного, методов обобщения, синтеза, индукции и дедукции. Ряд значимых выводов сделан с опорой на социологический метод исследования. Этический кодекс вуза - это свод правил поведения добросовестного участника образовательного процесса. Кодекс является удачным «компромиссом» между разными видами «этик»: преподавателя и студента, студента и работника администрации. В этой связи особенную ценность приобретает процесс обсуждения сценариев поведения участников отношений в критических ситуациях и закрепление наиболее эффективных выработанных подходов в кодексе. По своей юридической сути этические кодексы являются нормативными, но, как правило, неправовыми актами, поскольку они принимаются органами профессиональных сообществ и часто не подкрепляются силой государственного принуждения.

Ключевые слова: высшее образование, этика науки, этика образования, этический кодекс, кодекс этики вуза

Конфликт интересов. Авторы заявляют об отсутствии конфликта интересов.

Информация о вкладе авторов: Панарина М.М. - введение, поиск, анализ и научная проработка материалов, общий обзор, заключение; Фонотова О.В. — поиск материалов, правовой анализ, выводы, структура и редактирование текста, перевод статьи на английский язык.
\end{abstract}

Дата поступления в редакиию: 2 ноября 2020 г.

Дата принятия к печати: 15 апреля 2021 г.

\section{Для цитирования:}

Panarina M.M., Fonotova O.V. University codes of ethics: Legal nature and regulatory effect // RUDN Journal of Law. 2021. T. 25. № 2. C. 414 433. DOI: 10.22363/2313-2337-202125-2-414-433

"Our fate depends on our manners".

Cornelius Nepot, Roman historian

\section{Introduction}

The key task of practical ethics is to adapt individual behavior to permissible, acceptable forms of activity in specific areas of social life and to create an effective and predictable common model of behavior for all those involved in such interaction. Such 
benchmarks are set by codes of ethics: business ethics, ethics of consulting services, judicial ethics, medical ethics, teaching ethics, etc. (Botavina, 2003). The rapid development of specialized codes of ethics is linked to globalization, growing specialization of the economy, the need to regulate new types of social relations and development of the autonomy of will of the participants in such relations.

Ethics codes of universities come as a response to the need to regulate the diversity of relationships that emerge in the higher education and academic environment. Codes of ethics are designed to establish basic moral guidelines (norms and rules of conduct) for students in the process of university studies and to administer the activities of university staff. Unlike corporate codes of ethics common in the business community, university codes represent both professional and corporate (Zaporozhec, 2011) codification (Apresyan, 2009), while remaining codes of honour (see, for example, RUDN Faculty Code of Honour ${ }^{1}$, Code of Honour of Kazakh National Agrarian University ${ }^{2}$ ). Moral standards of the university environment, based on university spirit and traditions, serve as an indispensable moral reference point for codifications. Belonging to the university community, honouring teachers and alma mater by students are all an integral part of university ethics.

At the same time, the university is no longer perceived as a closed center of education and science, but as an active platform accessible to a wide range of researchers, a research and education corporation (Bakshtanovsky, Bogdanova \& Sogomonov, 2009), an open platform for education in many fields. The latter is achieved, among other things, through the intensive development of distance and online education.

We are confident that in today's conditions of higher education institutions (hereinafter - HEI)' development, given the wide range of tasks that universities face, a special mission is assigned to the HEI's code of ethics. Now it is not only a document formally fixing the rights and obligations of the participants in the educational process, but also an ideological text, a declaration of principles, a high reference point for the HEI's partners and society; it outlines the essence of the university in general, the directions of its development and the prospects of interaction with it.

Two key functions of higher education institutions' codes of ethics can be described as reputational and managerial. The first one is called to build and maintain the corporate culture, traditions, and image of the university. The second function focuses on creating a normative framework for governance and coordinating the university's internal activities. Thus, the reputational function is mainly aimed at having an external effect, an impact with centrifugal force, while the managerial function addresses the internal organizational processes.

With the enhanced role and presence of universities in society, including through digitalization of educational processes and the trend for greater openness of formerly closed academic structures, it seems that the reputational function of codes of ethics will occupy central place in universities' system of ethical standards. The higher

\footnotetext{
1 RUDN Faculty Code of Honour. Available at: http://www.rudn.ru/u/www/files//kodeks-chestiprepodavatelya-rudn.pdf [Accessed $07^{\text {th }}$ February 2021].

${ }^{2}$ Code of Honour of Kazakh National Agrarian University. Available at: http://www.kaznau.kz/page/ kyzmetkerler/?var=okytushylardyn_arnamys_kodeksi_565\&lang=ru [Accessed $07^{\text {th }}$ February 2021].
} 
education institution is becoming actively involved in economic processes. It is no longer a bystander, protected by the cloak of a strong state, but an active economic actor. Like any business corporation, HEI must take care of its status, fight for competitiveness, strive to climb up in ratings, and be ready to respond to many other social and economic challenges of local and international origin. The experience of international corporations shows that introduction of a code of ethics is one of the most effective and at the same time harmonious ways of solving complex problems ${ }^{3}$.

In our opinion, there is a progressive trend towards comprehensive improvement in regulating moral aspects of educational organizations' activities. Along with codes, universities in general are developing ideas of ethical regulation and formation of special bodies: ethical committees and commissions, academic ethics commissions ${ }^{4}$.

Drafting and publishing the text of a code of ethics for higher education institutions is not an end in itself. Of particular significance is the process of implementing and the actual impact of the codified guidelines on specific life situations; effective mechanisms for resolving problems and conflict become especially valuable. For example, the codes and accompanying documents detail effective algorithms for responding to the typical complaints and requests of participants in the educational process. This reveals the need to find common ground for different types of ethics (of a teacher and a student, of a student and an administration employee) in an attempt to find a compromise solution (Weingartner, 1999) and, finally, to maintain a balance of interests of all those concerned.

The basis of our research is the theory of communicative action developed by Jürgen Habermas in 1981 (Habermas, 1983). The theory involves search for optimal ways of mutual understanding, which is only possible when the community itself creates conventional rules of interaction. Consequently, the provisions of a HEI code of ethics are formed in the process of communication between the participants of the educational process and are fixed in the practice of their relations.

We have also drawn on the work of van Nuland on ethical principles, professional ethics and sets of beliefs ${ }^{5}$, as well as Poisson's writings on ethical norms and values ${ }^{6}$.

\footnotetext{
${ }^{3}$ For example, the practice of Apple Inc. to create effective mechanisms to enhance its international reputation (following the tragic events at the corporation's supplier factories in China in early 2012) included the consistent introduction of a code of ethics to govern relationships within the corporation and in the supply chain. This experience has been repeatedly described in literature, see: (Miller \& Meredith, 2013) Corporate Codes of Conduct and Working Conditions in the Global Supply Chain: Accountability Through Transparency in Private Ordering (October 20, 2013). Presented at 2013 West Virginia University College of Law as part of a conference titled "Business and Human Rights: Moving Forward, Looking Back". Available at: https://ssrn.com/abstract=2342756 [Accessed 07 $7^{\text {th }}$ February 2021].

${ }^{4}$ For example, on June 4, 2011 the Academic Ethics Commission of the Academic Council of the Higher School of Economics was created. Available at: https://www.hse.ru/us/academic_ethics [Accessed $08^{\text {th }}$ February 2021].

${ }^{5}$ Nuland, S. (van) (2009) Teacher Codes: Learning from Experience. International Institute for Educational Planning (IIEP), UNESCO [online]. Available at: https://rm.coe.int/tom-2-/168074cc74 [Accessed 30th October 2020].

${ }^{6}$ Poisson, M. (2009) Guidelines for the Design and Effective Use of Teacher Codes of Conduct. International Institute for Educational Planning (IIEP), UNESCO [online]. Available at: https://rm.coe.int/tom-2-/ $168074 \mathrm{cc} 74$ [Accessed 30th October 2020].
} 
It is worth noting that codes of ethics are currently being studied by philosophers (Safonov, 2013), sociologists (Tuguz \& Lyausheva, 2013), philologists (Gulius, 2015), psychologists ${ }^{7}$, specialists in technical sciences (Sidorin \& Sidorin, 2015) and other academics. However, the legal component seems to have been undeservedly neglected and fallen out of the research focus.

The university code of ethics remains an understudied phenomenon in Russian legal science, despite the diversity of relations regulated by it. A striking exception is the recent study of the legal nature of codes of ethics as a legal means of combating corruption, carried out by the Russian Academy of Sciences corresponding member A.V. Gabov and professor O.A. Yastrebov (Gabov \& Yasstrebov, 2020). The relevance of the legal research undertaken by us is confirmed by the wide range of addressees and significant scope of areas covered by the higher education organizations' ethics codes. The lack of a developed approach to the legal nature and mechanism of the regulatory impact of the rules of conduct presented in ethical codes significantly hinders the active development of such means of non-governmental regulation of social relations. Our study has been undertaken to fill in this gap.

\section{University Codes of Ethics: Essence and Legal Nature}

Ethical principles of education have been one of the central themes of philosophical debate for centuries. Ethics of education looks at the habitual behaviors that participants in educational interactions adhere to.

In the nineteenth and twentieth centuries university ethics and key values of the university were studied by authoritative researchers, including foreign scholars such as R.W. Barnett, M. Weber, J. Derrida, F. Nietzsche, X. Ortega y Gasset, L. Feuerbach, J.-H. Fichte, A.A. Fischer, M. Heidegger, G. Heimpel, G. Schneidelbach, A. Schopenhauer, K. Jaspers, and Russian scholars such as S.S. Uvarov and others (Savvina, 2011). In the USA, John Dewey exercised a significant influence on the development of ethical ideas about education, including higher school (Crosser, 1955; Goode, 1957).

The second quarter of the twentieth century is characterized by the increased attention that the American academic and business communities pay to ethical issues. As early as 1926, Edgar Heermanns explored the code of ethics as a tool for raising the level of moral values in society (Heermance, 1926).

From a legal perspective, codes of ethics are normative regulators. However, they are not traditionally regarded as legal acts and/or sources of law, as they are not adopted by state law-making bodies but by the professional community and are mainly aimed at regulating intra-organizational relations. This does not mean that their social impact is insignificant. On the contrary, the history of law is aware of cases where the norms of codes of ethics have become so relevant and significant that they have spilled over into law. Among the acts of this kind are the Model Code of Ethics and Official

\footnotetext{
${ }^{7}$ Druzhilov, S.A. (2015) Social and Psychological Problems of University Intellectuals in the Time of Reforms: the Teacher's View. Montreal, Accent Graphics Communications, T/O "NEFORMAT" [online]. Available at: https://libs.ru/book/355447/read/ [Accessed 30th October 2020]. (in Russian)
} 
Conduct of Civil Servants of the Russian Federation ${ }^{8}$, the Code of Judicial Ethics ${ }^{9}$, and the Code of Professional Ethics of an Advocate ${ }^{10}$. The examples mentioned are professional rules. The professional requirements set out in such documents are standardized at the level of generally binding behavioural patterns. The joint conclusion by corresponding member of the Russian Academy of Sciences A.V. Gabov and professor O.A. Yastrebov is of particular importance in this respect; according to the authoritative researchers, the anti-corruption provisions included in the codes of ethics in higher education are currently developing into legal norms (Gabov \& Yastrebov, 2020).

A person should perceive an ethical rule as a value for himself or herself and for society in general to properly follow it. In academia, this perception stems from the need for order and intrinsic motivation and is conditioned by the reasonableness of rule application for employee and other members of the university community. Karl Marx wrote: "No one can do anything without doing it, at the same time, for the sake of any of his needs..." (Marx \& Engels, 1956). Max Weber pointed out the need for deterministic interest if the behavior of the actor (participant) is to be instrumentally oriented. He noted, "if the mutually oriented social actions of individuals are performed regularly, then the regularity of these social ties must be conditioned by something..." (Veber, 1990). The concept of order presupposes typical patterns of behaviour that individuals follow and are guided by. It turns out that the university community should perceive the ethical norm as an important part of the legal and corporate culture for the norm to be respected in the most effective way. This idea is supported by the fact that university community follows the subjective determination and is aware of the importance of the norm in question for the whole society. Thus, the mechanism of an ethical rule is linked to the need for order, for a known course of action, which is embedded in the consciousness of an individual or a group of people.

A rule of the ethics code, unlike a habit, contains a so-called prescriptive component. The behavior set out in the code should be adhered to by all members of the university community, while breach of the relevant rule may lead to sanctions, including public censure, negative impact on a person's reputation, disciplinary measures, termination of employee's contract. A vivid illustration of the above feature of codes of ethics is the Student Code of Ethics of Plekhanov Russian University of Economics. This document contains the following rules: "1. For systematic or gross violations of the provisions of this Code, the Student Council can apply various forms of moral penalties to the violators. The University administration shall be entitled at its own discretion to impose disciplinary actions against the violators of the provisions of this Code as provided by the Charter and the University's internal regulations. 2. The community of students shall have the right to establish on their own initiative arbitration tribunals, courts of honor to resolve situations related to violations of the provisions of

\footnotetext{
${ }^{8}$ Model Code of Ethics and Official Conduct of Civil Servants of the Russian Federation. Available at: http://www.consultant.ru/document/cons_doc_LAW_113505 [Accessed 07th February 2021].

${ }^{9}$ Code of Judicial Ethics. Available at: http://www.ksrf.ru/ru/Info/LegalBases/Kodeks/Pages/default.aspx [Accessed 07th February 2021].

${ }^{10}$ Code of Professional Ethics of an Advocate. Available at: https://fparf.ru/documents/fpa-rf/documentsof-the-congress/the-code-of-professional-ethics-of-lawyer/ [Accessed 07th February 2021].
} 
this Code" ${ }^{11}$. This example shows that the sanctioning component of the Code of Ethics focuses on coercive measures, which are more of a social than legal nature.

Educational institution is a special academic environment whose social influence can extend far beyond the boundaries of an individual HEI. The Charter (Code of Ethics) of the Higher School of Economics' employees (hereinafter - the Charter of HSE employees) correctly identifies the global role of ethical rules: "...these rules govern our own activities, our interaction with other employees and students, our behaviour towards the University and towards society as a whole" ${ }^{\text {. }}$.

University is a complex community, a living organism. At different stages of university development, different forms of interaction between the participants of academic and related processes are formed and evolve. It should be noted that such interaction actors may not have a direct connection with the university but be involved in the processes taking place in the university environment. University partners that conclude cooperation agreements with the university, representatives of public and governmental organizations that officially address the university administration, a prospective applicant interested in the rules of admission to university - all these persons and many others act within a certain regulatory system of rules established for universities, as well as formulated by university itself.

Primarily, we are talking about legal regulation in its classical sense, i.e., about federal legislation ${ }^{13}$, legislation of constituent entities of the Russian Federation (hereinafter - RF) $)^{14}$, and/or normative legal acts of executive authorities ${ }^{15}$. In addition, non-state regulating acts, including charters of educational institutions, codes of ethics and local regulations, make a significant contribution to creating a regulatory framework for relations in the academic and near-academic environment.

Codes of ethics are discussed and drafted by a range of specialists: experts in the relevant field, representatives of employers' associations and trade unions, employees of educational, scientific, and other institutions and organizations, lawyers and other interested persons. Draft codes are subject to expert review for compliance with laws and regulations ${ }^{16}$. These complicated technological features of codes formation testify to high standards set by society to such regulatory acts and to high standards of legal technique in drafting them.

\footnotetext{
${ }^{11}$ Student code of ethics Russian University of Economics. G. V. Plekhanova. Available at: https://www.rea.ru/ ru/org/branches/kursk/Pages/kodeks-studenta.aspx [Accessed 07th February 2021].

${ }^{12}$ Charter (code of ethics) for HSE employees. Available at: https://www.hse.ru/our/news/ 376333150.html\#code [Accessed 07th February 2021].

${ }^{13}$ Federal Law No. 273-FZ On Education in the Russian Federation of December 29, 2012. Hereinafter, if the source or pages of the publication are not mentioned, it means that its electronic text (or source), included in the Consultant Plus database, was quoted.

${ }^{14}$ Law No. 828-KZ of December 29, 2004 On Education of Krasnodar Krai; Law No. 12-2674 of December 3, 2004 On Education of Krasnoyarsk Krai; Law of Kursk Region No. 13-ZKO of February 17, 2000 On Education in Kursk Region.

${ }^{15}$ Resolution No. 295 of the Government of the Russian Federation of April 15, 2014 On Approval of the State Program of the Russian Federation 'Development of Education' for the years of 2013 - 2020.

${ }^{16}$ Order of the Ministry of Labor of Russia No. 671n of September 30, 2014 On Approval of Methodological Recommendations on the Organization of Professional and Public Discussion and Expertise of Draft Professional Standards.
} 
This, however, does not necessarily imply that a set of ethical rules should inevitably be given the force of a legal act. From the analysis of the set of ethical regulations, we conclude that a code of ethics in an educational institution is a general concept of an average conscientious participant's behaviour in a particular situation during educational process. Following this approach, university codes of ethics do not require them to be given the force of a local normative (legal) act, as they do not conflict with the legal system, but only complement, enhance its effectiveness on social relations in socio-economic and moral aspects. To illustrate the idea, the Charter of HSE employees declares: "The Charter is not a local normative act of the University and has the nature of a convention (general agreement) adopted by its staff as a basis for individual and joint actions..., violation of the ethical standards formulated in the Charter does not in itself entail disciplinary responsibility, but is censured by the university community..., conscious or systematic violation of the Charter is considered an act of contempt to colleagues and disagrees with the University interests" ${ }^{\prime 17}$.

\section{International Practice of University Codes of Ethics' Implementation}

In developed foreign countries, the practice of codifying academic ethics has deep historical roots. In the United States of America, the birth of ethical codes is associated with the American Association of University Professors (AAUP) ${ }^{18}$. Founded in 1915, the Association helped to shape American higher education by developing standards and procedures to support the quality of education and academic freedom in US colleges and universities. In the first half of the twentieth century, the Association established the Council on University Ethics, chaired by John Dewey, and produced several professional and ethical documents. However, the modern foundations of academic ethics as a system of regulation were laid in the 1966 Statement on Professional Ethics. This authoritative document, subsequently revised in 1987 and 2009, declares the basic standards of conduct for North American academics, given the diverse responsibilities associated with this professional role ${ }^{19}$.

Foreign academic literature captures strong interest of contemporary researchers in the ethical component of the educational process in foreign HEIs and the ways of its implementation in the academic environment. In his publication British researcher $\mathrm{J}$. Moore notes that practice of adopting codes of ethics in the UK universities has become widespread. He draws attention to the fact that the current framework of university ethical policy is based on generally accepted corporate practice of implementing codes of ethics and goes far beyond the traditional emphasis on research ethics. Furthermore, the author points out that such regulatory acts are introduced simultaneously with accompanying mechanisms to ensure practical implementation of ethical rules (Moore, 2006).

\footnotetext{
${ }^{17}$ Charter of HSE. Available at: https://www.hse.ru/our/news/376333150.html\#code [Accessed 07th February 2021].

${ }^{18}$ Ethical codes is associated with the American Association of University Professors (AAUP). Available at: https://www.aaup.org/ [Accessed 07th February 2021].

19 Statement on Professional Ethics. Available at: https://www.aaup.org/NR/rdonlyres/DCB2B487-5ACF400C-BCAA-118A27788B57/0/EthicsStmt.pdf [Accessed 07th February 2021].
} 
US legal scholars highlight the importance of university codes of ethics in resolving global problems that extend well beyond the university walls. In his research on the effectiveness of universities' ethical standards in fighting corruption, a Texas based scholar V. Johnson asserts that a code of ethics is not just desirable; it is an essential element of best practice to achieve tangible results in anti-corruption efforts (Johnson, 2012).

Academic ethics in its codified embodiment has become a hot research topic not only in developed countries but also in developing jurisdictions. For example, we have encountered rather interesting publications on this theme by academics in Pakistan (Hamza \& Ahmed, 2016) and India (Sharma \& Kapoor, 2013). The papers emphasize the special role of codes of ethics in the academic environment in these countries and identify the specific benefits of introducing such regulation at the university level.

Educational organizations around the world have developed and enacted codes of ethics or other acts of ethical concern in recent decades. Codes of ethics or codes of conduct in academia have been adopted by many (if not all) leading HEIs, including Harvard University $(2014)^{20}$, California Institute of Technology (2002) ${ }^{21}$, Cornell University (1997) ${ }^{22}$, Stanford University $(2007)^{23}$, Swiss Federal Institute of Technology (2007) ${ }^{24}$ and others. An important motivation for global HEIs is the university ranking system: the functioning of the ethical regulatory framework at the HEI is considered, among other things, when assigning ratings.

It is interesting to note the heterogeneity of the contents of the above-mentioned codes and differences in their mechanism of action. Some codes are detailed, complex documents, while others are acts of a general nature, articulating aspirational guidelines. For example, the set of ethical regulations at Harvard University consists of several documents. The Code of Ethics contains the basic principles of academic ethics which are binding for faculty members and students (e.g., it deals with academic honesty, respect for independence in academic work, prohibition of unwarranted borrowing of others' research results, etc.). A separate code of conduct for students includes guidelines for creating a safe environment in the university: respect for private property, prohibition of possession and consumption of alcohol, etc.

Most of the codes are supplemented by regulations prescribing the establishment of specialized services and structures at different levels to deal with critical situations. Ethics acts in foreign universities are supported by an internal system of ethical

\footnotetext{
${ }^{20}$ Harvard Honor Code. Available at: https:/honor.fas.harvard.edu/honor-code [Accessed 07th February 2021].

21 A Code of Ethics for Caltech. Doing Business. The Caltech Way: An Ethics Handbook. Available at: http://codeofconduct.caltech.edu/documents/1-caltech_statement_on_ethical_conduct-april_ 2014.pdf [Accessed 07th February 2021].

${ }^{22}$ Code of Academic Integrity. Available at: https://www.library.cornell.edu/research/citation/code. [Accessed 07th February 2021].

${ }^{23}$ University Code of Conduct. Available at: https://adminguide.stanford.edu/chapter-1/subchapter-1/policy1-1-1 [Accessed 07th February 2021].

24 Weisungen betreffend Meldungen von Angehörigen der ETH Zürich zu rechtlich und ethisch unkorrektem Verhalten. Available at: http://www.rechtssammlung.ethz.ch/pdf/130.1_weisungen-unkorrVerhalten-ETHZ.pdf [Accessed 07th February 2021].
} 
regulation and response. Such system is represented by specially formed internal bodies (committees, commissions, etc.) for ethics, applied ethics research centers, complaints acceptance services, ethics hotlines and other institutionalized mechanisms of comprehensive impact.

In regulating ethical issues in education, international instruments of non-state origin play a special role. Among them, the following instruments stand out: 2004 EI Declaration on Professional Ethics (authored by Education International - the federation of teachers' trade unions); 2012 IAU-MCO Guidelines for an Institutional Code of Ethics in Higher Education (by the International Association of Universities and Magna Charta Observatory); 2004 Bucharest Declaration concerning Ethical Values and Principles in Higher Education in the Europe Region (adopted at the International Conference on Ethical and Moral Dimensions for Higher Education and Science in Europe by the UNESCO European Centre for Higher Education (UNESCOCEPES)); UNESCO 1997 Recommendation concerning the Status of Higher Education Teaching Personnel; 2005 European Charter for Researchers and Code of Conduct for the Recruitment of Researchers (adopted by the European Commission).

According to these documents, university instructors shall conduct their professional activity in full compliance with ethical and professional standards. Such activity should, wherever possible, address contemporary problems facing society and preserve the historical and cultural heritage of society. Some ethical standards were recommended by UNESCO "as a basis for developing an ethical code of conduct for the teaching profession".

\section{Features of Russian Jurisprudence on Ethics-Related Disputes}

Practice shows that Russian courts have difficulties in determining the legal nature of ethical rules. Because of this, judicial practice on disputes relating to violations of ethical rules of HEIs has not yet developed in Russia. There are only isolated cases and insignificant number of resolved disputes, which at this stage do not allow any unequivocal conclusion about the general trend of the judicial approach to the problem in question.

The legal basis for claims in connection with disputes in the academic environment is represented by the Federal Law No. 273-FZ On Education in the Russian Federation of 29 December 2012. According to the requirements of part 4 of Article 43 of this Law "for non-compliance or violation of the charter of the organization that carries out educational activities, internal regulations, rules of residence in dormitories and boarding schools and other local normative acts on the matters concerning organization and implementation of educational activities, students may be subjected to disciplinary sanctions — an admonition, a reprimand, an expulsion from the organization that carries out educational activities".

A study of citizens' complaints in respect of law violations, including noncompliance with higher education institutions' codes of ethics, has shown that the grounds for complaints usually include non-compliance with the basic obligations of participants of educational interaction set out in the code of ethics of the higher 
education institution, such as the use of profanity, bullying, violation of the student dormitory routine ${ }^{25}$, discipline ${ }^{26}$ and public order rules ${ }^{27}$.

The court appeals against unlawful dismissal from higher education institutions deserve particular attention as a breach of scientific and educational ethics may be the reason for dismissing an employee from university as a workplace. Thus, in one case, a university lecturer appealed against his dismissal from the university. The reason for the dismissal was a memo from the head of the accounting department, P.V., dated .... N...., according to which ...L. violated his official duties, work discipline, and "grossly failed to fulfill the instructions of the head of the department on a regular basis". An employee of the university did not submit lecture notes and teaching materials on the courses taught by the department ${ }^{28}$; at the beginning of the first semester of the 2013 - 2014 academic year, L. refused to teach the course of Accounting and Analysis assigned to him by the department for far-fetched reasons. At the same time, the lecturer indicated in the appeal that he "...expected support and proper investigation in accordance with generally recognized norms of academic ethics, provisions of the Charter of the university, collective agreement and rules of internal labour procedure. However, he received neither support, nor protection, to say nothing about professionally qualified investigation of the conflicts" 29 . The panel of judges overturned the lower court decision and reinstated the lecturer in his position. It was determined that the employer had not previously sent the trade union body a notice (with a draft dismissal order attached, as well as copies of the documents, which formed the basis for the decision on dismissal) on the approval of termination of the employment contract with L. due to repeated failure to perform his job duties. Thus, the defendant did not comply with the procedure established by Article 373 of the Russian Labour Code for considering the reasoned opinion of the elected body of the primary trade union organization in dismissal cases. The court referred to those facts as the ground for reinstating $\mathrm{L}$. in his teaching position.

Another set of disputes concerning operation of ethics rules in HEIs relates to cases of disciplinary sanctions imposed on employees. For example, once, the reason for initiating court proceedings was a claim by a lecturer to recognize unlawful both the order to form a teaching and methodological commission and the order to impose disciplinary liability on that person as a staff member. The teaching and methodological commission had been set up to check compliance of the lecture on criminal enforcement law with the requirements of the curriculum and the teaching and methodological complex of the discipline. The plaintiff considered those actions unlawful, as he had been entrusted with two contradictory duties at the same time: conducting seminars and examination session. According to the lecturer: "...holding pass-fail exam session at the time set for the classroom studies is a breach of the plans of educational and methodical work and workshop activities; as a result the students

\footnotetext{
25 Ruling of the Prikubansky District Court of Krasnodar of July 07, 2014 relating to case No. 2-5579/2014 M-5584/2014.

${ }^{26}$ Appeal Ruling of the Kemerovo Regional Court of June 24, 2014 relating to case No. 33-6015.

${ }^{27}$ For example, participation in an interpersonal conflict. See the Cassation Ruling of the Belgorod Regional Court of August 02, 2011 relating to case No. 33-2751.

${ }^{28}$ Appeal Ruling of the Moscow City Court of October 10, 2014 relating to case No. 33-25253.

${ }^{29}$ Appeal Ruling of the Moscow City Court of October 10, 2014 relating to case No. 33-25253.
} 
did not gain the required number of points for credit; the dean of the faculty had instructed to work off the students' debts with the points accumulated on the test date (...), thus... actually forcing them to violate the established rules and norms of the educational process..." ${ }^{30}$. The court found no reason to support the lecturer's claim and recognise the order that imposed disciplinary liability on him unlawful: "...based on the Regulations on the modular rating system of the educational process in OSAU, a credit for the discipline is put automatically when the student reaches the threshold number of points in the rating of current performance and does not imply any independent teaching process in accordance with the curriculum and class schedule. In the opinion of the court, the calculation of the rating points gained by a student at each of the milestones of the current progress control is a simple arithmetic procedure, for which the curriculum and class schedule do not provide additional time...."31.

A different view is reflected in a court decision, which invalidated an order imposing disciplinary action on an employee for breaching local code of ethics, namely, publicly accusing an authority of corrupt practices ${ }^{32}$. According to this code, the employee must behave impeccably, not deviate from ethical norms and maintain a positive reputation and image of the organization during working and non-working hours. The employee's statement was considered a breach of this provision and qualified by the employer as disciplinary misconduct. The Court of First Instance found unethical behavior on the part of the employee but concluded that those actions did not constitute disciplinary misconduct. The Court of Appeal supported that conclusion, additionally stating that ethics is an established norm of behavior in society, noncompliance with which entails public censure. The code in question did not disclose what constituted a deviation from ethical standards or what kind of deviation could constitute disciplinary misconduct. The wording of the provision in the code does not allow to distinguish between the conduct of an employee which entails only a public censure and the conduct which constitutes a disciplinary offence. Therefore, in the dispute at hand, the court concluded that there were no grounds for disciplinary action against the employee.

As has already been mentioned, the ethics enforcement system is based on a non-legal sanction framework. At the same time, the use of codes of ethics involves all participants of educational interaction in the process of improving the ethical system of education, including formation of a solution bank of ethical cases of the educational institution.

Ethical norms occupy a special position in the system of regulators of social relations. On the one hand, they do not imply a strict control system like the law but, on the other hand, ethical norms can serve as a reason (grounds) for calling a person to disciplinary liability.

It is worth mentioning that norms of a code of ethics providing for legal sanctions (if any) should be clearly worded to avoid legal uncertainty in a controversial situation. For example, an anti-corruption duty (providing, for instance, for an obligation to report an inducement to commit a corruption offence) must be supplemented with

\footnotetext{
${ }^{30}$ Ruling of the Leninsky District Court of Orenburg of June 02, 2016 relating to case No. 2-3966/2016.

${ }^{31}$ Ruling of the Leninsky District Court of Orenburg of June 02, 2016 relating to case No. 2-3966/2016.

32 Appeal Ruling of the Perm Krai Court of August 26, 2013 relating to case No. 33-7779-2013.
} 
relevant regulations specifying the persons to be imposed with such duty, the legal fact which gives rise to the duty and the time frame for reporting misconduct. This detailing is crucial since in the future the norm of the code in question may serve as a basis for holding a person at least liable for disciplinary action and a declaratory rule of the code can cause dramatic problems (unreasonable imposition of liability or, conversely, inability to hold a person liable).

\section{Classification and Structure of University Codes of Ethics}

The comparative study of existing university codes of ethics allows us to propose a classification of such regulations according to the following criteria:

Action by a circle of persons: (1) codes that apply to the academic community (examples: Code of Ethics of the Lomonosov Moscow State University ${ }^{33}$, Code of Academic Ethics of $\mathrm{RGGU}^{34}$ ); (2) codes regulating behavior of employees (examples: Code of Ethics of University Community of Ural Federal University ${ }^{35}$, Code of Ethics and Official Conduct of Employees of Lobachevsky Nizhny Novgorod State University ${ }^{36}$ ); (3) codes addressed to students (example: RUDN Student Code of Honour $^{37}$, Code of Ethics of a student at Plekhanov Russian University of Economics $^{38}$ ).

In terms of legal force: (1) codes adopted as a local normative act and endowed therefore with an appropriate legal characteristic (example: RUDN Student Code of Honour ${ }^{39}$ ); and (2) codes without the force of a legal act, i.e., not approved as a local act of an educational organization; represents an informal agreement of members of the university community (example: Charter (code of ethics) of HSE employees ${ }^{40}$ ).

In terms of the manner of imposing liability, the following are distinguished: (1) codes that list basic types of violations without specifying penalties but making a reference to labour legislation (example: Code of Ethics for Teachers, Employees and Students of Kutafin Moscow State Law University ${ }^{41}$ ); and (2) codes that establish (describe) specific types of penalties - recommendations, appeals, expulsion of

\footnotetext{
${ }^{33}$ Code of Ethics of the Lomonosov Moscow State University. Available at: http://sc.law.msu.ru/pages/ eticheskiy_kodeks_mgu [Accessed 07th February 2021].

${ }^{34}$ Code of Academic Ethics of RGGU. Available at: https://www.rsuh.ru/upload $/ \mathrm{main} / \mathrm{science} / 2018 / \%$ D0\%9A\%D0\%BE\%D0\%B4\%D0\%B5\%D0\%BA\%D1\%81\%20\%D0\%B0\%D0\%BA\%D0\%B0\%D0\%B4\%D0 \%B5\%D0\%BC\%D0\%B8\%D1\%87\%D0\%B5\%D1\%81\%D0\%BA\%D0\%BE\%D0\%B8\%CC\%86\%20\%D1\%8 D\%D1\%82\%D0\%B8\%D0\%BA\%D0\%B8\%202018.pdf [Accessed 07th February 2021].

${ }^{35}$ Code of Ethics of University Community of Ural Federal University. Available at: https:/urfu.ru/ fileadmin/user_upload/common_files/employee/other/Kodeks_ehtiki.pdf [Accessed 07th February 2021].

${ }^{36}$ Code of Ethics and Official Conduct of Employees of Lobachevsky Nizhny Novgorod State University. Available at: http://www.unn.ru/site/images/docs/obrazov-org/76-OD.pdf [Accessed 07th February 2021].

${ }^{37}$ RUDN Student Code of Honour. Available at: http://www.rudn.ru/u/www/files/corporate_culture_slider/ kodeks-chesti-obuchayushchego-s-dopolneniyami-1.docx [Accessed 07th February 2021].

38 Code of Ethics of a student at Plekhanov Russian University of Economics. Available at: https://www.rea.ru/ru/org/branches/kursk/Pages/kodeks-studenta.aspx [Accessed 07th February 2021].

${ }^{39}$ RUDN Student Code of Honour. Available at: http://www.rudn.ru/u/www/files/corporate_culture slider/kodeks-chesti-obuchayushchego-s-dopolneniyami-1.docx [Accessed 07th February 2021].

${ }^{40}$ Charter (code of ethics) of HSE employees. Available at: https://www.hse.ru/our/news/376333150. html\#code [Accessed 07th February 2021].

${ }^{41}$ Employees and Students of Kutafin Moscow State Law University. Available at: https://msal.ru/common/ upload/Eticheskiy_kodeks_Universiteta.pdf [Accessed 07th February 2021].
} 
students, dismissal of employees (example: Code of Corporate Ethics of Kuban State Agrarian University ${ }^{42}$ ).

Based on an analysis of higher education institutions' codes of ethics, an effective model structure for a university code of ethics may include the following:

1) Code's focus - ethical guidelines for the activities of the team of higher education institution represented by professors, lecturers, researchers, teaching and research support staff, and administrative staff, whose common efforts are aimed at fulfilling the mission of the institution and strengthening its prestige in society.

2) Code's purpose - the key provisions (basic ideas) of the code's creation.

3) Code's application - the sphere of application of the code.

4) Values of the university corporation - basic concepts, traditions and principles of the university, a description of these fundamentals.

5) Rights and obligations of the educational process participants - we suggest including in this section the description of the algorithm of participants' actions in real life situations aimed at overcoming conflicts and maintaining the balance of interests of the persons involved in the educational process. In this section, it is also recommended to exclude vague formulations and to avoid the possibility of ambiguous interpretations regarding the moral attitudes and behavioural scenarios of the parties.

6) Relations with third parties - is an extremely important section of the code, reflecting the HEI's policy in its relations with the outside world. For example, we believe that a university employee is its representative, and when expressing his/her opinion publicly, they must remember and be aware of this. Such a rule should be enshrined in the context of regulating the employee's relations with the HEI partners, public organizations, and state bodies. It is recommended to specify in the code who has the right to respond on behalf of the HEI to official requests of state bodies, and who among the employees has limited access to certain information, so that he/she cannot be regarded as a person competent to respond to such requests from external persons.

7) Liability — this section should enumerate specific sanctions for violations of the code of ethics' provisions and describe the rules for their application. It is useful to detail the procedural aspects: define the internal body that takes decisions on imposing penalties, the principles of its work and organization of activities, etc.

8) Adherence to the code - the text must specifically state that ignorance of the code cannot serve as an excuse for unethical behavior.

9) Final provisions - terms and procedure of adoption of the code, peculiarities of its publication and enactment, procedure, and periodicity of updating the code. This section may also define the procedure of mandatory familiarization with the code (and amendments / additions to it) of all persons to whom it is addressed.

For convenience, the table below summarizes the contents of current codes of ethics of several Russian universities (see Table 1). As the study has shown, in the absence of a unified reference material, the codes vary greatly from one another. The differences are found in names, content, and legal nature of these acts. Codes differ depending on the procedure of their enactment, on the ways of coercive influence on

\footnotetext{
${ }^{42}$ Code of Corporate Ethics of Kuban State Agrarian University. Available at: https://kubsau.ru/upload/ university/docs/corpetica2017.pdf [Accessed 07th February 2021].
} 
the addressees of norms, on the ways of establishing liability. Spheres and ways of regulation are also rather heterogeneous. It seems that the development of a model university code of ethics at the federal level could be useful for a more fruitful development of an ethics-oriented approach in Russian universities. This document could reflect the most effective best practices used by Russian and foreign universities to ensure ethical behaviour.

Table 1. Russian HEI's Ethics Codes

\begin{tabular}{|c|c|c|c|c|c|}
\hline $\begin{array}{l}\text { Ethics Code's } \\
\text { Name }\end{array}$ & $\begin{array}{c}\text { Sphere of Regula- } \\
\text { tion }\end{array}$ & $\begin{array}{l}\text { Regulatory } \\
\text { Method }\end{array}$ & $\begin{array}{l}\text { Manner of Imposing } \\
\text { Liability }\end{array}$ & $\begin{array}{c}\text { Order } \\
\text { of Adoption }\end{array}$ & $\begin{array}{c}\text { Best Practices / } \\
\text { Unfortunate Wording } \\
\text { of Ethical Norm }\end{array}$ \\
\hline $\begin{array}{l}\text { Charter (Code of } \\
\text { Ethics) of the } \\
\text { Higher School } \\
\text { of Economics' } \\
\text { employees } \\
\text { (July 01, 2020) }\end{array}$ & $\begin{array}{l}\text { The Charter is a } \\
\text { set of academic, } \\
\text { professional and } \\
\text { social norms that } \\
\text { outline accepted } \\
\text { and unacceptable } \\
\text { actions of employ- } \\
\text { ees at the Univer- } \\
\text { sity. These norms } \\
\text { regulate HSE's } \\
\text { own activities, } \\
\text { interaction with } \\
\text { other employees } \\
\text { and students, and } \\
\text { behaviour towards } \\
\text { the University and } \\
\text { society in general. }\end{array}$ & $\begin{array}{l}\text { Recom- } \\
\text { mendation }\end{array}$ & $\begin{array}{l}\text { Breach of the ethical } \\
\text { standards set forth in } \\
\text { the Charter does not } \\
\text { entail disciplinary } \\
\text { liability but is censured } \\
\text { by the university } \\
\text { community and can be } \\
\text { referred to the } \\
\text { Academic Ethics } \\
\text { Commission of the } \\
\text { HSE Academic } \\
\text { Council and other } \\
\text { ethics commissions } \\
\text { formed by the Univer- } \\
\text { sity. }\end{array}$ & $\begin{array}{l}\text { Formally } \\
\text { approved by } \\
\text { the HSE Ac- } \\
\text { ademic } \\
\text { Council fol- } \\
\text { lowing pro- } \\
\text { cedure of } \\
\text { social legiti- } \\
\text { mization } \\
\text { and public } \\
\text { discussion } \\
\text { of the draft } \\
\text { Charter. }\end{array}$ & $\begin{array}{l}\text { Principles of academic } \\
\text { freedom, search for } \\
\text { scientific truth, and } \\
\text { strengthening the } \\
\text { reputation of the } \\
\text { University. The Char- } \\
\text { ter has been drafted for } \\
\text { the purpose of profes- } \\
\text { sional development of } \\
\text { the University's } \\
\text { employees, creating } \\
\text { comfortable working } \\
\text { atmosphere for them. }\end{array}$ \\
\hline $\begin{array}{l}\text { Code of } \\
\text { Professional } \\
\text { Ethics and } \\
\text { Professional } \\
\text { Conduct of } \\
\text { Employees of } \\
\text { the Federal State } \\
\text { Autonomous } \\
\text { Educational } \\
\text { Institution of } \\
\text { Higher } \\
\text { Education } \\
\text { "National } \\
\text { Research } \\
\text { Technological } \\
\text { University } \\
\text { 'MISIS"' } \\
\text { (October 13, } \\
\text { 2017) }\end{array}$ & $\begin{array}{l}\text { The Code serves } \\
\text { as the basis for the } \\
\text { formation of } \\
\text { proper morale in } \\
\text { the sphere of } \\
\text { of providing edu- } \\
\text { cational services, } \\
\text { respectful public } \\
\text { attitude to the } \\
\text { employees of the } \\
\text { University and } \\
\text { acts as a source of } \\
\text { public conscious- } \\
\text { ness and morale of } \\
\text { the University } \\
\text { employees, their } \\
\text { self-control }\end{array}$ & $\begin{array}{l}\text { Permis- } \\
\text { sion, obli- } \\
\text { gation }\end{array}$ & $\begin{array}{l}\text { Liability for breaches } \\
\text { of the norms and rules } \\
\text { of the Code involves } \\
\text { condemnation by the } \\
\text { public opinion of the } \\
\text { University staff, disci- } \\
\text { plinary action against } \\
\text { the employee, as well } \\
\text { as imposing other } \\
\text { forms of liability in } \\
\text { accordance with the } \\
\text { Russian laws. An em- } \\
\text { ployee's compliance } \\
\text { with the provisions of } \\
\text { the Code may be } \\
\text { considered while } \\
\text { imposing disciplinary } \\
\text { penalties in the event } \\
\text { the employee has } \\
\text { committed immoral } \\
\text { acts, which are } \\
\text { incompatible with } \\
\text { his/her professional } \\
\text { duties, or position, as } \\
\text { well as when reward- } \\
\text { ing employees who } \\
\text { perform their job } \\
\text { duties conscientiously }\end{array}$ & $\begin{array}{l}\text { The Code, } \\
\text { as well as its } \\
\text { amendments } \\
\text { and addi- } \\
\text { tions } \\
\text { are ap- } \\
\text { proved by } \\
\text { the Rector } \\
\text { of the Uni- } \\
\text { versity or a } \\
\text { person au- } \\
\text { thorised by } \\
\text { him/her and } \\
\text { is subject to } \\
\text { agreement } \\
\text { with the pri- } \\
\text { mary trade } \\
\text { union organ- } \\
\text { isation of } \\
\text { MISIS' } \\
\text { employees }\end{array}$ & $\begin{array}{l}\text { The Code, unfortu- } \\
\text { nately, does not in- } \\
\text { clude provisions on } \\
\text { conflicts of interest, on } \\
\text { employee interactions } \\
\text { with third parties, or } \\
\text { the media, but it estab- } \\
\text { lishes important princi- } \\
\text { ples for relations with } \\
\text { students, namely: } \\
\text { "University teaching } \\
\text { staff may themselves } \\
\text { choose such methods } \\
\text { of work that encourage } \\
\text { in students the devel- } \\
\text { opment of such posi- } \\
\text { tive traits and qualities } \\
\text { as independence, } \\
\text { initiative, responsibil- } \\
\text { ity, self-control, } \\
\text { self-education, } \\
\text { desire to cooperate } \\
\text { with friends and help } \\
\text { others ..." (item 3.7) }\end{array}$ \\
\hline
\end{tabular}




\begin{tabular}{|c|c|c|c|c|c|}
\hline $\begin{array}{l}\text { Ethics Code's } \\
\text { Name }\end{array}$ & $\begin{array}{l}\text { Sphere of Regula- } \\
\text { tion }\end{array}$ & $\begin{array}{l}\text { Regulatory } \\
\text { Method }\end{array}$ & $\begin{array}{c}\text { Manner of Imposing } \\
\text { Liability }\end{array}$ & $\begin{array}{c}\text { Order } \\
\text { of Adoption }\end{array}$ & $\begin{array}{c}\text { Best Practices / } \\
\text { Unfortunate Wording } \\
\text { of Ethical Norm }\end{array}$ \\
\hline $\begin{array}{l}\text { Code of Ethics } \\
\text { and Professional } \\
\text { Conduct of } \\
\text { Employees of } \\
\text { the Federal } \\
\text { State Budgetary } \\
\text { Educational } \\
\text { Institution of } \\
\text { Higher } \\
\text { Education } \\
\text { "National } \\
\text { Research } \\
\text { University } \\
\text { "MPEI"' } \\
\text { (April 21, 2017) }\end{array}$ & $\begin{array}{l}\text { The Code estab- } \\
\text { lishes general rules } \\
\text { and standards of } \\
\text { conduct for the } \\
\text { University em- } \\
\text { ployees, affecting } \\
\text { the ethics of rela- } \\
\text { tionships and is } \\
\text { aimed at fostering } \\
\text { ethical, conscien- } \\
\text { tious behavior of } \\
\text { MPEI's employ- } \\
\text { ees in general. } \\
\text { The Code applies } \\
\text { to all MPEI } \\
\text { employees } \\
\text { irrespective of the } \\
\text { position held and } \\
\text { functions } \\
\text { performed. }\end{array}$ & \begin{tabular}{|l|} 
Recom- \\
mendation \\
(the Code \\
does not \\
contain a \\
clause on \\
its \\
validity; it \\
seems \\
necessary \\
to intro- \\
duce such \\
a provi- \\
sion)
\end{tabular} & $\begin{array}{l}\text { Compliance with the } \\
\text { provisions of the Code } \\
\text { by the MPEI } \\
\text { employees } \\
\text { is considered when } \\
\text { forming the personnel } \\
\text { reserve for promotion } \\
\text { to higher positions, as } \\
\text { well as when imposing } \\
\text { disciplinary penalties }\end{array}$ & $\begin{array}{l}\text { Approved } \\
\text { by the } \\
\text { Rector }\end{array}$ & $\begin{array}{l}\text { Several provisions of } \\
\text { the Code require } \\
\text { further clarification. } \\
\text { For instance, item 1.5: } \\
\text { "Knowledge and ob- } \\
\text { servance of the provi- } \\
\text { sions of this Code by } \\
\text { the University employ- } \\
\text { ees is one of the crite- } \\
\text { ria for evaluating the } \\
\text { quality of their profes- } \\
\text { sional activity and } \\
\text { labour discipline"- } \\
\text { should be evaluated in } \\
\text { conjunction with the } \\
\text { requirements of cur- } \\
\text { rent labour legislation } \\
\text { and local normative } \\
\text { acts, as well as proce- } \\
\text { dure of employees' } \\
\text { certification; item } 4.2 \text { : } \\
\text { "The provisions of this } \\
\text { Code are to be consid- } \\
\text { ered while forming } \\
\text { the personnel pool for } \\
\text { promotion to higher } \\
\text { positions, as well as } \\
\text { imposing disciplinary } \\
\text { penalties on the em- } \\
\text { ployees"- requires } \\
\text { additional specification } \\
\text { in correlation with } \\
\text { other provisions of the } \\
\text { Code and application } \\
\text { of disciplinary } \\
\text { measures. }\end{array}$ \\
\hline $\begin{array}{l}\text { Code of Ethics } \\
\text { and Professional } \\
\text { Conduct of } \\
\text { Employees of } \\
\text { the Federal State } \\
\text { Budgetary } \\
\text { Educational } \\
\text { Institution of } \\
\text { Higher Educa- } \\
\text { tion "Kazan } \\
\text { National } \\
\text { Research } \\
\text { Technological } \\
\text { University" } \\
\text { (December 21, } \\
\text { 2017) }\end{array}$ & $\begin{array}{l}\text { The Code is a set } \\
\text { of general princi- } \\
\text { ples of profes- } \\
\text { sional ethics and } \\
\text { basic rules of } \\
\text { professional } \\
\text { behaviour that } \\
\text { must be followed } \\
\text { by university } \\
\text { employees regard- } \\
\text { less of the position } \\
\text { they hold. The } \\
\text { University } \\
\text { employees } \\
\text { covered by this } \\
\text { Code shall include } \\
\text { those who work at } \\
\text { the University and } \\
\text { hold positions of } \\
\text { teaching staff } \\
\end{array}$ & \begin{tabular}{|l|} 
Recom- \\
menda- \\
tion, \\
obligation
\end{tabular} & $\begin{array}{l}\text { Compliance with the } \\
\text { provisions of the Code } \\
\text { may be considered in } \\
\text { certification of teach- } \\
\text { ing staff for their posi- } \\
\text { tion, in application of } \\
\text { disciplinary penalties, } \\
\text { as well as promotion } \\
\text { of employees who } \\
\text { perform their job } \\
\text { duties in good faith }\end{array}$ & $\begin{array}{l}\text { The Code, } \\
\text { as well as its } \\
\text { amendments } \\
\text { and addi- } \\
\text { tions, are } \\
\text { approved by } \\
\text { an order of } \\
\text { the Rector } \\
\text { of the } \\
\text { University, } \\
\text { taking into } \\
\text { account the } \\
\text { opinion of } \\
\text { the primary } \\
\text { trade union } \\
\text { organization } \\
\text { of employ- } \\
\text { ees }\end{array}$ & $\begin{array}{l}\text { The Code does not } \\
\text { include provisions on } \\
\text { conflicts of interest, on } \\
\text { interaction of } \\
\text { employees with third } \\
\text { parties and the media. } \\
\text { To prevent ethical } \\
\text { dilemmas and conflict } \\
\text { situations, appropriate } \\
\text { regulation should be } \\
\text { included in the } \\
\text { document. }\end{array}$ \\
\hline
\end{tabular}




\begin{tabular}{|c|c|c|c|c|c|}
\hline $\begin{array}{l}\text { Ethics Code's } \\
\text { Name }\end{array}$ & $\begin{array}{l}\text { Sphere of Regula- } \\
\text { tion }\end{array}$ & $\begin{array}{c}\text { Regulatory } \\
\text { Method }\end{array}$ & $\begin{array}{l}\text { Manner of Imposing } \\
\text { Liability }\end{array}$ & $\begin{array}{c}\text { Order } \\
\text { of Adoption }\end{array}$ & $\begin{array}{c}\text { Best Practices / } \\
\text { Unfortunate Wording } \\
\text { of Ethical Norm }\end{array}$ \\
\hline & $\begin{array}{l}\text { belonging to the } \\
\text { teaching staff, } \\
\text { researchers, as } \\
\text { well as positions } \\
\text { of administrative, } \\
\text { engineering, tech- } \\
\text { nical, support and } \\
\text { other types of } \\
\text { personnel accord- } \\
\text { ing to the staff } \\
\text { schedule approved } \\
\text { in accordance with } \\
\text { the established } \\
\text { procedure, or hired } \\
\text { to perform a } \\
\text { specific type of } \\
\text { work }\end{array}$ & & & & \\
\hline $\begin{array}{l}\text { Code of Ethics } \\
\text { and Professional } \\
\text { Conduct of } \\
\text { Employees and } \\
\text { Instructors of } \\
\text { National } \\
\text { Research } \\
\text { University } \\
\text { "MEPhI" } \\
\text { (June 17, 2016) }\end{array}$ & $\begin{array}{l}\text { The Code is } \\
\text { a local normative } \\
\text { act that defines } \\
\text { moral and ethical } \\
\text { principles, norms, } \\
\text { rules of conduct } \\
\text { and business } \\
\text { communication at } \\
\text { the University }\end{array}$ & $\begin{array}{l}\text { Recom- } \\
\text { menda- } \\
\text { tion, obli- } \\
\text { gation }\end{array}$ & $\begin{array}{l}\text { Compliance with the } \\
\text { Code is considered in } \\
\text { electoral and } \\
\text { competitive proce- } \\
\text { dures, in the formation } \\
\text { of a personnel reserve, } \\
\text { as well as in solving } \\
\text { issues of encourage- } \\
\text { ment or imposition } \\
\text { of disciplinary } \\
\text { penalties }\end{array}$ & $\begin{array}{l}\text { Procedure } \\
\text { for adopting } \\
\text { a local nor- } \\
\text { mative act }\end{array}$ & $\begin{array}{l}\text { Item 7.3: "Enforce- } \\
\text { ment of this Code is } \\
\text { based on moral } \\
\text { self-control of employ- } \\
\text { ees of the University" } \\
\text { seems unfortunate, as } \\
\text { it contradicts item } 1.1 \\
\text { of the Code, which } \\
\text { states that the Code is } \\
\text { a local normative act. } \\
\text { From the same point } \\
\text { of view, items } 4.5 \text {. and } \\
4.6 \text { of the Code on the } \\
\text { regulation of employee } \\
\text { telephone and e-mail } \\
\text { communication should } \\
\text { be re-considered. } \\
\text { These provisions refer } \\
\text { to aspects of } \\
\text { employees' private } \\
\text { life, so it seems } \\
\text { doubtful to provide for } \\
\text { such regulation in a } \\
\text { local normative act. }\end{array}$ \\
\hline
\end{tabular}

\section{Conclusion}

Based on the results of a comprehensive analysis of Russian and international ethics codes of higher education institutions, legislation, and judicial practice, we conclude that academic codes of ethics are one of the most important regulators of relations among the participants of the educational process inside and outside university. These documents consider the needs and interests of a wide range of stakeholders, as well as multitude of interactions between them. Such way of regulating relationships makes it possible to create flexible and effective management systems and mechanisms. A distinctive feature of effective development and application of 
codes is discussion and reflection of experience in resolving typical situations faced by participants in the academic process.

Codes of ethics are well-established and sustainable acts of regulation; they reflect the actual state of affairs, contain norms identified (formulated) by the university community in consensus. This justifies the effectiveness of university codes of ethics and their wide dissemination in the academic environment. In addition, codes of ethics have found wide application in regulating relationships mediated by or related to the academic sphere.

Empirical data shows that the interest of the university and legal community in Russia in studying, improving, and popularizing codes of ethics and the rules of conduct contained in them is steadily growing. At the same time an important role is given to prompt response to changes in public relations and, accordingly, work on systematic updating of codes is also in demand. In this respect we consider it expedient to create working groups within research centers and institutes to form standards of behaviour, model rules and model codes of ethics of higher educational institutions. It seems that the activities of such groups will further advance ethical standards of domestic educational organizations and strengthen the position of Russian universities in the global academic community.

\section{References / Список литературы}

Apresyan, R.G. (2009) On the Ethical Codification of University Life. Terms of Opportunity. Vedomosti NIIJeP: Code of Ethics of the University. (34), 69-85. (in Russian).

Апресян Р.Г. Об этическом кодифицировании университетской жизни. Условия возможности // Ведомости НИИЭП. Вып. 34: Этический кодекс университета. 2009. C. $69-85$.

Bakshtanovsky, V., Bogdanova, M. \& Sogomonov, Yu. (2009) University as a ScientificEducational Corporation: Dualism of Self-Identification and the Choice of Priority. Russian Journal of Philosophical Sciences. (3), 78-95. (in Russian).

Бакштановский В.И., Богданов М.В., Согомонов Ю.В. Университет как научно-образовательная корпорация: дуализм самоидентификации и выбор приоритета // Философские науки. 2009. № 3. С. 78 - 95.

Botavina, R.N. (2003) Ethics of Business Relations. Textbook for economic specialties. Moscow, Finance and Statistics Publ. (in Russian).

Ботавина Р.Н. Этика деловых отношений: Учебное пособие по экономическим специальностям. М.: Финансы и статистика, 2003. 206 с.

Crosser, P. (1955) The Nihilism of John Dewey. Michigan, Philosophical Library.

Gabov, A.V. \& Yastrebov, O.A. (2020) Local acts of Universities as a means of combating corruption. RUDN Journal of Law. 24 (2), 252-273. DOI: 10.22363/2313-2337-2020-242-252-273. (in Russian).

Габов А.В., Ястребов О.А. Локальные акты вузов как средство противодействия коррупции // Вестник Российского университета дружбы народов. Серия: Юридические науки. 2020. Т. 24. № 2. C. 252-273. DOI: 10.22363/2313-2337-2020-24-2-252-273

Goode, W.J. (1957) Community within a Community: The Professions. American Sociological Review. 22 (2), 194-200.

Gulius, N. S. (2015) Code of ethics of the university as a tool of the corporate culture transformation (case based on the activities of the National Research Tomsk State University). In: Talent management and corporate culture transformation: materials of the International 
conference "HR trend 2015: talent management and corporate culture transformation". Tomsk, pp. 184-188. (in Russian)

Гулиус Н.С. Этический кодекс университета как инструмент трансформации корпоративной культуры (кейс на материале деятельности Национального исследовательского Томского государственного университета) // Управление талантами и трансформация корпоративной культуры: материалы Международной конференции «HR-тренд 2015: управление талантами и трансформация корпоративной культуры». Томск, 2016. C. $184-188$.

Habermas, Jü. (1983) Moralbewusstsein und Kommunikatives Handeln. Social theory, 2nd edition. Suhrkamp. (in German).

Hamza, M.A. \& Ahmed, A. (2016) The Existential Paradox between Code and Conduct: Decoupling and Its Far-Reaching Consequences in Higher Education. Pakistan Journal of Commerce and Social Sciences. 10 (3), 547-568. Available at: https://ssrn.com/abstract=2986377 [Accessed: 07th February 2021].

Heermance, E.L. (1926) The Ethics of Business: A Study of Current Standards. New York, Harper \& Bros.

Johnson, V. (2012) Higher Education, Corruption, and Reform. Contemporary Readings in Law and Social Justice. 4 (1), 478 - 495. Available at: https://ssrn.com/abstract=2891936 [Accessed: 07th February 2021].

Marx, K. \& Engels, F. (1956) From an Early Work. T. 3. Moscow, Politizdat Publ. (in Russian). Маркс К., Энгельс Ф. Из ранних произведений. Т. 3. М.: Политиздат, 1956. 629 с.

Moore, G. (2006) Managing Ethics in Higher Education: Implementing a Code or Embedding Virtue? Business Ethics: A European Review. 15 (4), 407-418. DOI: http://dx.doi.org/ 10.1111/j.1467-8608.2006.00462.x

Safonov, K.B. (2013) Ethical codes: problems of creation and application. Perm University Herald. Series "Philosophy. Psychology. Sociology”. 1 (13), 54-57. (in Russian).

Сафонов К.Б. Этические кодексы: проблемы создания и применения // Вестник Пермского университета. Философия. Психология. Социология. 2013. Вып. 1 (13). С. $54-57$.

Savvina, O.V. (2011) Academic Ethics: General Principles and Applied Aspects. Diss ... cand. in Philosophy of sciences. Moscow, Lomonosov Moscow State University. (in Russian).

Саввина O.B. Академическая этика: общие принципы и прикладные аспекты: дис ... канд. философ. наук. М.: Моск. гос. ун-т им. М.В. Ломоносова. 2011. 169 с.

Sharma, J. \& Kapoor, N. (2013) Teachers' Role in University Governance - A Study of University of Delhi. Journal of Commerce and Business Studies, Delhi School of Economics, University of Delhi. Available at: https://ssrn.com/abstract=2996376 [Accessed: 07th February 2021].

Sidorin, A.V. \& Sidorin, V.V. (2015) The University Code of Ethics as the Basis for the Corporate Culture of the Technical University. Standard Model. University Management: Practice and Analysis. (1), 104-119. (in Russian).

Сидорин A.B., Сидорин В.B. Этический кодекс вуза как основа корпоративной культуры технического университета. Типовая модель // Университетское управление: практика и анализ. 2015. № 1. С. 104-119.

Tuguz, F.K. \& Lyausheva, S.A. (2013) Ethical code of the University as a resource for students' socialization. The Bulletin of the Adyghe State University, the series "Region Studies: Philosophy, History, Sociology, Jurisprudence, Political Sciences and Culturology”. 4 (130), 164-173 (in Russian)

Тугуз Ф.К., Ляушева С.А. Этический кодекс университета как ресурс социализации студентов // Вестник Адыгейского государственного университета. Серия: Регионоведение: философия, история, социология, юриспруденция, политология, культурология. 2013. № 4 (130). С. 164-173.

Veber, M. (1990) Selected Works. Translation from German; Compilation, general edition and afterword by Davydov Yu.N. Moscow: Progress Publ. (in Russian). 
Вебер М. Избранные произведения : пер. с нем. / составление, общая редакция и послесловие Ю.Н. Давыдова. М.: Прогресс, 1990. 808 с.

Weingartner, R.H. (1999) Moral Dimensions of Academic Administration. Lanham.

Zaporozhec, O.N. (2011) University as a Corporation: Intellectual Cartography of Research Approaches. Moscow, Higher School of Economics Publ. (in Russian)

Запорожеи О.Н. Университет как корпорация: интеллектуальная картография исследовательских подходов. М.: Изд. дом Высшей школы экономики, 2011. 48 с.

\section{About the authors:}

Maria M. Panarina - Candidate of Legal Sciences, Associate Professor of the School for Theory of Law and Cross-sectoral Legal Disciplines, the Faculty of Law, National Research University Higher School of Economics (NRU HSE); 20 Myasnitskaya str., Moscow, 101000, Russian Federation

ORCID ID: 0000-0002-4560-0857, SPIN- code: 3381-2402

e-mail: mmpanarina@hse.ru

Olga V. Fonotova - Candidate of Legal Sciences, Associate Professor of the School of Legal Regulation of Business, the Faculty of Law, National Research University Higher School of Economics (NRU HSE); 20 Myasnitskaya str., Moscow, 101000, Russian Federation

ORCID ID: 0000-0003-2255-9684, SPIN- code: 9663-0526

e-mail: ofonotova@hse.ru

\section{Об авторах:}

Панарина Мария Михайловна - кандидат юридических наук, доцент Департамента теории права и межотраслевых юридических дисциплин, факультет права, Национальный исследовательский университет «Высшая школа экономики»; 101000, Российская Федерация, г. Москва, ул. Мясницкая, д. 20

ORCID ID: 0000-0002-4560-0857, SPIN- код: 3381-2402

e-mail: mmpanarina@hse.ru

Фонотова Ольга Владимировна - кандидат юридических наук, доцент Департамента правового регулирования бизнеса, факультет права, Национальный исследовательский университет «Высшая школа экономики»; 101000, Российская Федерация, г. Москва, ул. Мясницкая, д. 20

ORCID ID: 0000-0003-2255-9684, SPIN- код: 9663-0526

e-mail: ofonotova@hse.ru 